\title{
The Pliocene-Pleistocene
}

\section{Boundary}

\section{by E. Aguirre and G. Pasini}

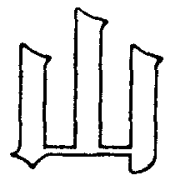

At the 1977 INQUA Congress, the membership of the ICS Working Group and the INQUA Subcommission was reorganized, and the present authors were elected as Chairman (E.A.) and Secretary (G.P.) of both bodies. Since then the work of the Group has concentrated on identifying the different problems involved, on establishing the pertinent criteria and, not least, on arriving at a common terminology and a common understanding of the whole matter.

Four linked questions were distinguished: first, designation of a type area; second, selection of a type section; third, selection of a plane in the type section as a basis for defining the lower boundary of the Pleistocene; and finally, the recognition of the Pliocene-Pleistocene Boundary outside the type area, or in other words, the means of correlating the Boundary on a global scale. The subject of defining the Boundary between the Pliocene and Pleistocene was isolated from other more or less related problems, such as the pending definition of the Calabrian, and the status of the Quaternary within the chronostratigraphic scale.

At the end of a Field Conference on the Boundary held in the Panjab and Kashmir in 1979 (Sastry et al., 1981), a decision was adopted to minimize change from the general intention of the 1948 Congress recommendation. Two decisions of that Congress were emphatically confirmed: to establish the Boundary in accordance with generally accepted principles of stratigraphy, and to select a type section in the Upper Cenozoic marine sequences of southern Italy. On the other hand, two statements of the 18th IGC Session were definitely rejected: the equivalence of the continental "Villafranchian" with the marine "Calabrian," and the acceptance of the first

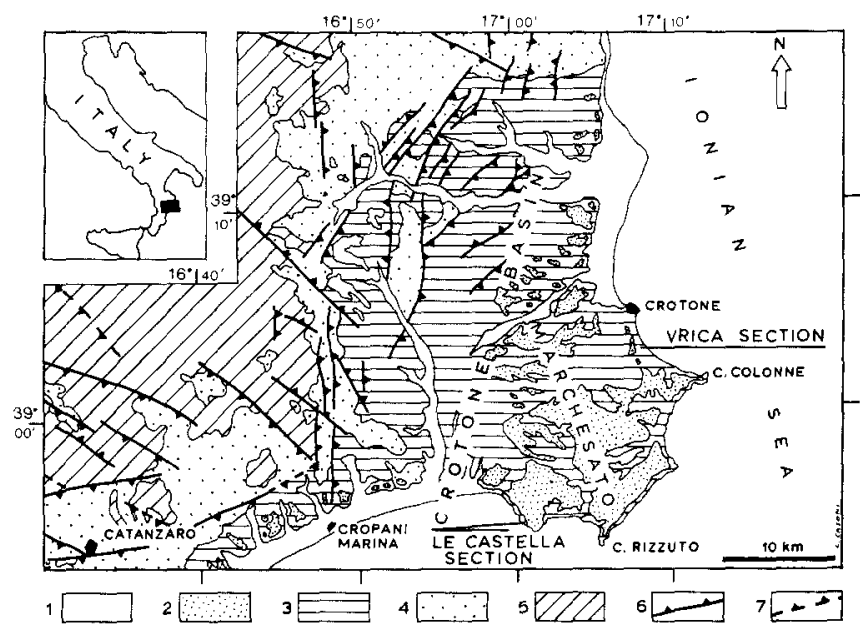

Figure 1: Geological map of the Marchesato Peninsula (after Tortorici, 1982). I - Continental sediments (Pleistocene and Holocene), 2 - Sediments of upper Pleistocene marine terraces, 3 - Middle to upper Pliocene and lower Pleistocene sediments, 4 Tortonian to lower Pliocene sediments, 5 - Basement rocks, 6 - Main faults (small triangles on downthrown sides), 7 - Possible faults. 
climatic deterioration in the Italian Plio-Pleistocene succession as the main criterion for defining the base of the Pleistocene. The participants of the 1979 Conference in India unanimously acknowledged that the Vrica section was more suitable than those of Santa Maria di Catanzaro and Le Castella for defining a basal boundary stratotype for the Pleistocene Series.

\section{Work on the Vrica Section}

Early in 1980 , a postal enquiry was circulated to all Voting and Corresponding Members of the Working Group in order to determine which of these three sections was considered as most suitable for a boundary stratotype, and which criteria they preferred for choosing it. The Santa Maria di Catanzaro section was rejected as a type section in 40 of the 46 answer's, with 6 undecided and not a single reply in favour; the Le Castella section was considered unsuitable by 34 members, approved by l, with 11 not answering. The Vrica section was approved by 33 members and rejected by 3 , with 10 members undecided. The alleged disadvantages of the Santa Maria di Catanzaro section were: dubious or shallowwater facies, partially reworked faunas, presence of several unexposed intervals, and a hiatus at the base. The main reasons why the Le Castella section was rejected were: relative lack of thickness of strata, the presence of a hiatus approximately at the level proposed by Emiliani et al. (1961) as the Pliocene-Pleistocene Boundary, and general difficulty in access.

Substantial progress was made on the occasion of the 26 th Session of the IGC in Paris, 1980, in a joint meeting of the Boundary Working Group and IGCP Projeet 4l. The decision was made to place the Pliocene-Pleistocene Boundary stratotype in the Vrica Section. The wording of the definition was distinguished explicitly from the criteria for selecting that boundary plane. The former had to be at a single bedding plane, whereas the latter should "be multiple; that is all the available evidence, which can help wide range correlations, should be taken into account." The first occurrence of the ostracode Cytheropteron testudo (considered to be a "northern guestit in the Vrica section, the sapropelic layer $\mathrm{e}$ within the section and its proximity to a paleomagnetic reversal were singled out for special attention, although a final decision on the boundary stratotype was deferred.

The need for further paleomagnetic research on the Vrica section was stressed at a joint Field Conference of IGCP Projects 41 and 128, held in Arizona and California (U.S.A.) in 1981. Such work was soon carried out both by ItalianAmerican and Japanese teams, working independently (see Fig. 3, right hand columns).

Finally, during a joint meeting of the INQUA Subcommission 1-D and IGCP Project 41 held in Moscow in 1982, a recommendation was approved to place the Pliocene-Pleistocene Boundary stratotype at the level of the first appearance of $\mathrm{C}$. Testudo in the Vrica section (considered pene-contemporaneous with the first appearance of the molluse Arctica islandica in Italian shallow water sections). Early in $1 \frac{983 \text { this }}{98}$ recommendation, and the alternative proposal of placing the Pliocene-Pleistocene Boundary stratotype strictly in relation to a particular marker bed of the Vrica section, were submitted to the Voting and Ex-officio Members of the ICS Working Group for a postal ballot.

The result was a tie, 8 to 8 . The officers of the Working Group meeting in Madrid in May 1983 agreed to make a new, joint proposal, designating the Pliocene-Pleistocene Boundary stratotype at Vrica by a lithostratigraphic plane related to the sapropelic marker bed e (Fig. 3). K.V. Nikiforova, as Leader of IGCP Project $\overline{41}$, and M.N. Alekseev, ViceChairman of the ICS Subcommission on Quaternary Stratigraphy, attended that meeting. A new ballot in July of the same year favoured this proposal for definition, with 12 votes for, 1 against and 2 abstentions; one more vote in favour was received later. The proposal was consequently submitted to

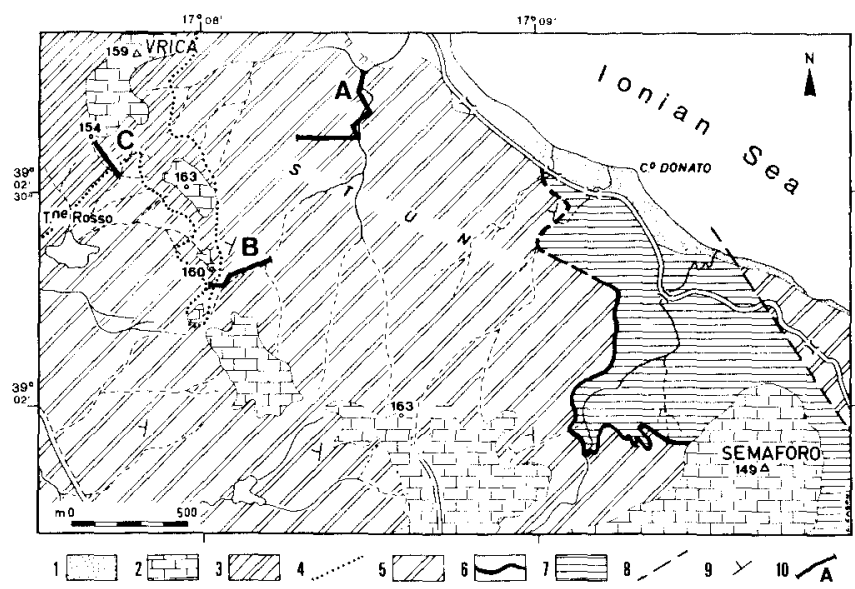

Figure 2: Geological map of the Vrica area (modified from Selli et al., 1977). I - Beach sand and dunes, 2 - Calcarenites and sands of the "Milazzian" marine terrace, 3 - Grey silty and marly claystones with intercalated sapropelic layers (lower Pleistocene), 4 - First appearance of Hyalinea baltica, $35 \mathrm{~m}$ above the $m$ volcanic ash layer (1.99 Ma), 5 - Grey silty and marly claystones with intercalated sapropelic layers (lower Pleistocene, upper and middle Pliocene), 6 - Lower volcanic ash layer (I.a.; 2.22 Ma), 7 - Grey claystones (middle Pliocene), 8 Faults, 9 - Strike and dip, 10 - Key stratigraphic sections.

the ICS Quaternary Subcommission, which also functions as the Commission on Stratigraphy of INQUA; it was approved by an affirmative vote of 9 of its Members, with no negative answer received. Finally, the proposal was submitted formally to the ICS Meeting at the 27th Session Geological Congress, Moscow 1984. In this session it was approved by the attending Members of the ICS to be forwarded in a postal ballot to Voting Members of the Commission. Ratification by IUGS is reported by M.G. Bassett in the accompanying paper.

The submission comprises two separate but linked resolutions: firstly, the selection of the Vrica section as the Pliocene-Pleistocene Boundary stratotype section; and secondly, the definition of the Pliocene-Pleistocene Boundary - that is, the base of the Pleistocene series - at the base of the marine claystones comformably overlying the marker bed $e$ in the Vrica section.

\section{The Stratotype Section and Boundary Correlation}

The Vrica section, located $4 \mathrm{~km}$ south of Crotone in the Marchesato Peninsula, Calabria, Italy (Fig. 1), consists of open sea deposits preserved in the emergent portion of a late Cenozoic sedimentary basin. The rocks are bathyal, marly and silty claystones (dark grey or blue-grey in colour) with interbedded, fairly conspicuous, pale grey-pink sapropelic marker beds. Some very thin sandy horizons and a volcanic ash layer also occur within the section (Figs. 2 and 3 ).

The Vrica section has been favoured by the Working Group since 1975 and was given preference in 1980 for various reasons. First, it is easily accessible, continuously exposed, and free from both vegetation and debris. It shows a good vertical development of strata, with some $306 \mathrm{~m}$ of beds exposed, and there is stratigraphic continuity throughout. Sedimentation rates through the section range from $310 \mathrm{~mm}$ to more than $750 \mathrm{~mm}$ per thousand years, There are neither structural complications nor metamorphism. The facies are bathyal and there are numerous fossils of different groups, several of which are suitable for widespread correlations (Fig. 3). Conditions recommended for current guidelines in stratigraphic classification (e.g. Hedberg, 1976) relating to a type section are therefore fully satisfied in the Vrica section. 


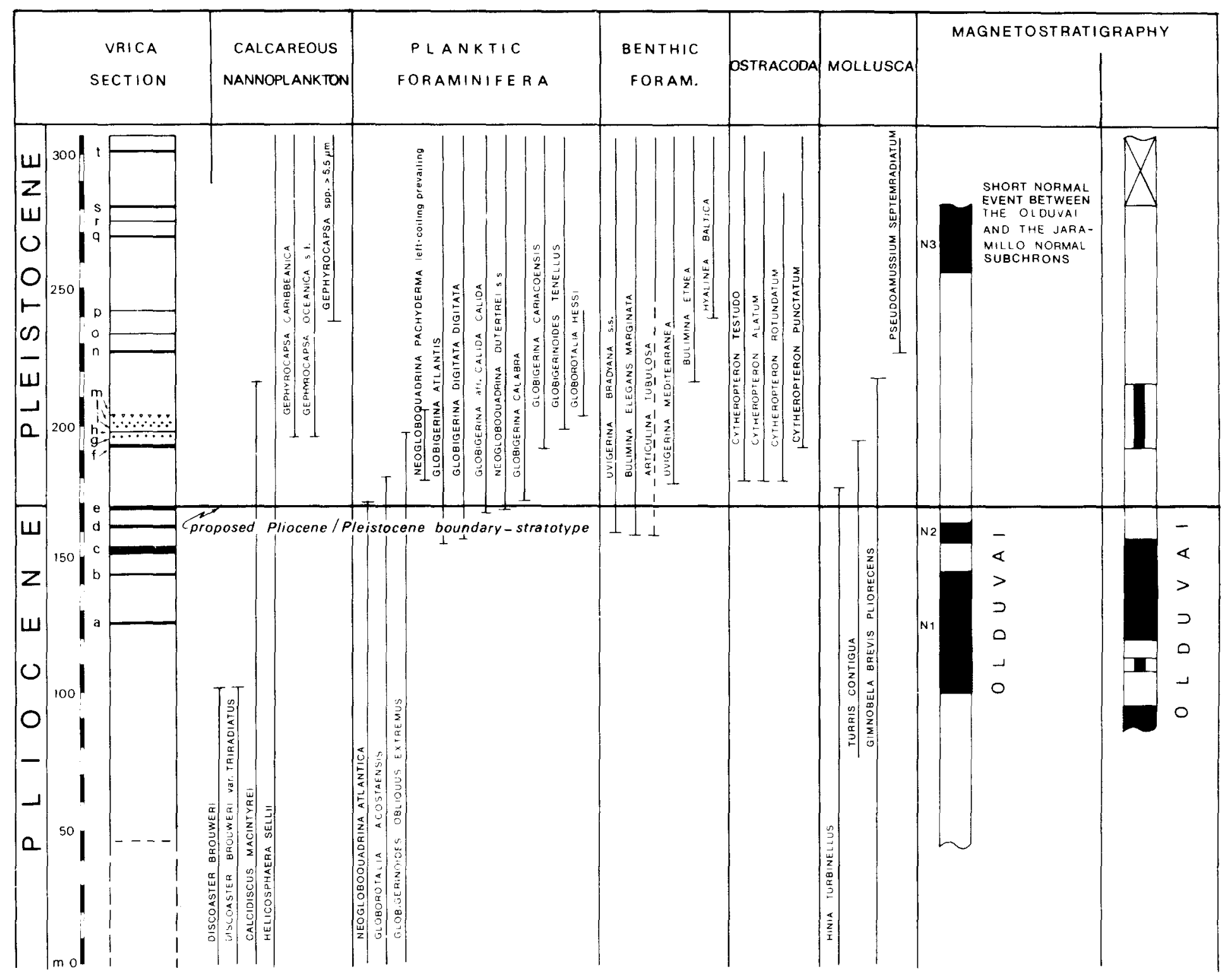

Figure 3: Distribution in the Vrica section of the most significant planktonic and benthic organisms from biostratigraphic and biochronologic points of view. Magnetostratigraphy in the left-hand column is based on Tauxe and others (1983) and in the right-hand column on Nakagawa (1983 personal communication, and in Van Couvering et al., in press). 


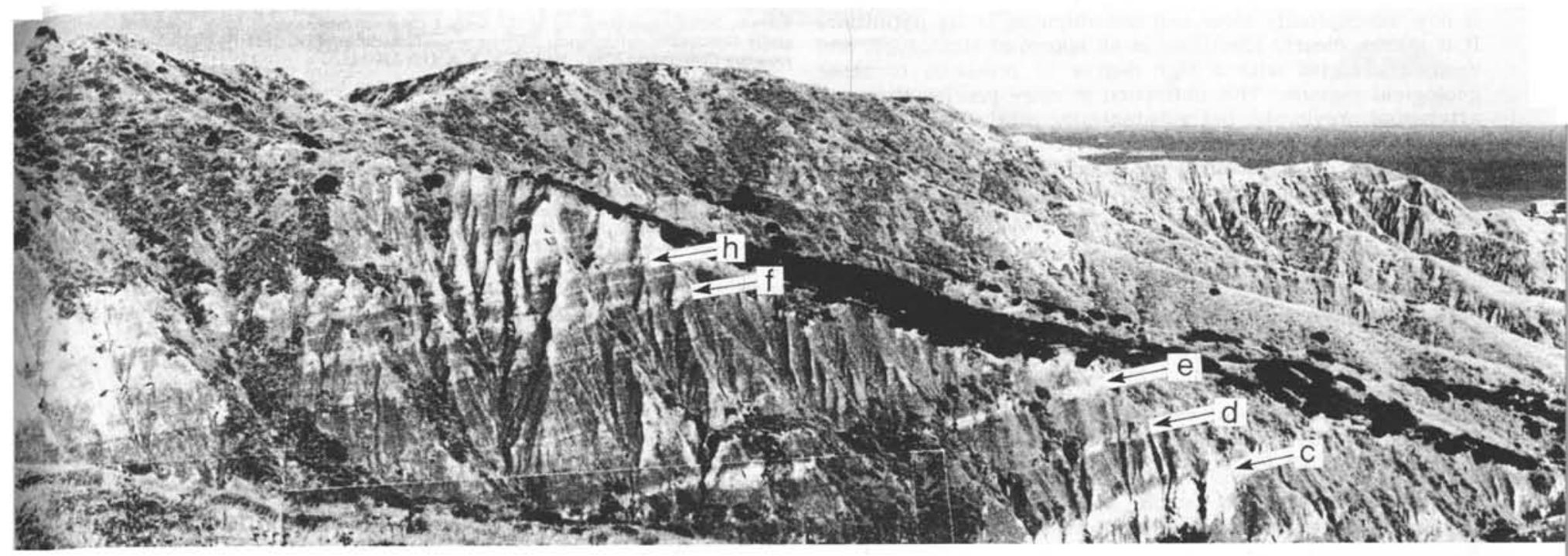

Figure 4: Section B of Figure 2, in foreground. On the right, the uppermost part of section $A$ and the Costa Tiziana Hotel are visible. The basal boundary stratotype for the Pleistocene series is defined at the base of the bed immediately overlying marker bed e.

Records of changes in magnetic polarity have also been reported at Vrica (Nakagawa, in Sastry et al., 1981). Interpretation of these records was controversial initially, but following new and independent research carried out by Tauxe and others (1983) and further work by Nakagawa and co-workers (in Van Couvering et al., in press), no doubt can remain as to the identification of the normal polarity zone below marker bed e with the Olduvai subchron (see Fig. 3). We strongly recommend that a goal of this Working Group in the immediate future should be the establishment of parastratotype, or hypostratotype sections in other appropriate marine basins and in continental sequences. We suggest that, among others, the Boso Peninsula in Japan and one of the good sections in East Africa, such as Olduvai Gorge in Tanzania, Koobi Fora in Kenya, or the Shungura formation of the lower Omo Basin, Ethiopia, should be considered for this purpose.

The second part of the submission reflects the agreement on the definition of the Pliocene-Pleistocene Boundary and its boundary stratotype. The base of the bed of silty marly claystone conformably overlying the sapropelic bed e at Vrica was selected as the precise boundary marker point for many reasons.

The fact that several paleontologic events (first and last occurrences of microfossils) straddling the proposed boundary stratotype occur in Italian shallow-water sections near the first appearance of the molluse Aretica islandica (the most renowned "northern guest") is fundamentally important. In fact, the first appearance of A. islandica in the Mediterranean area, and in particular in the Italian sequences, has been for decades one of the main criteria for defining the base of the Pleistocene Series.

Some of the paleontologic events occurring closely above and below the selected boundary plane are, both individually and collectively, quite reliable for widespread correlations. They include (Fig. 3) the last occurrence of the calcarceous nannoplankton Discoaster brouweri (below), the last occurrences of the foraminifer Globigerinoides obliquus extremus and the nannoplankton Calcidiscus macintyrei (above), and the first appearance of the nannoplankton Gephyrocapsa oceanica (above). In fact, these paleontological events are found in the same order and in the same position with respect to the
Olduvai magnetostratigraphic subchron both in the Vrica section and in oceanic deep sea cores. Therefore, the defined basal boundary of the Pleistocene Series can be correlated with very good precision within other marine sequences.

The identification of the Olduvai subchron in the Vrica section is also very important because reference to the magnetostratigraphic scale and to radiometric age determinations are the only current means for correlating continental sequences with the boundary stratotype. Relatively little attention has so far been paid to correlations between marine and non-marine deposits. Nevertheless continental deposits are extensive worldwide and deserve careful consideration in geologic research and mapping, especially as far as the late Cenozoic is concerned (Aguirre et al., in Van Couvering et al., in press).

The datum selected as the boundary level in the stratotype is quite conspicuous and identifiable; bed $\mathrm{e}$ can be traced throughout the outcrop and distinguished from the other sapropelic marker beds by its thickness (about $190 \mathrm{~cm}$ ) and relative position (Figs. 3 and 4). Moreover, this bed in common with the other sapropelic beds in the section is clearly distinguishable from the underlying and overlying clay strata because of its finely laminated structure and the markedly different colours involved.

The age of the volcanic ash layer in the Vrica section ( $\mathrm{m}$ in Fig. 3) has not yet been determined precisely. Obradovich and his co-workers (1982) could only demonstrate that this layer is certainly younger than $1.99 \pm 0.08 \mathrm{Ma}$. However, accepting the age of $1.67 \mathrm{Ma}$ for the top of the Olduvai subchron (Mankinen and Dalrymple, 1979) and considering that the sedimentation rate in the interval of the Vrica section between the top of the Olduvai and the top of marker bed $\mathrm{e}$ is $310 \mathrm{~mm}$ per thousand years (Tauxe et al., 1983), it follows that the age of the defined basal Pleistocene boundary point is about $1.64 \mathrm{Ma}$. This age is confirmed by independent calculations based on nannofossil biochronology (Rio and others, in Van Couvering et al., in press).

\section{Concluding Statement}

The definition of the beginning of the Pleistocene no longer has a primary climatic implication, which, because of latitudinal and altitudinal effects on world climate, would be difficult to provide. In some area the earliest glacial periods will be Pliocene age, or even older; in others they will be of mid-Pleistocene age. Precise definition of the base of the Pleistocene Series now provides a fixed reference point for such events in different regions. 
We believe that the basal boundary of the Pleistocene Series is now conceptually clear and unambiguous in its definition. It is stable, clearly identified in an approved stratotype, and easily correlated with a high degree of precision to other geological regions. This definition is more precise than any attempted previously, but substantially retains the concepts widely accepted in the past for the position of the base of Pleistocene. Consequently it should be understandable, acceptable and unequivocal as a practical standard by all geologists.

\section{Acknowledgements}

We are deeply indebted to R. Hey and R.P. Suggate, who patiently helped us by reading and correcting the language in successive manuscripts of the Boundary Proposal and of this summary account, as well as to the late A. Martinsson, to M.G. Bassett and to K.V. Nikiforova and her team in IGCP Project 41 for their most valuable advice. Financial aid was furnished by IUGS, INQUA, the Italian CNR, the Spanish IGME and CAICYT Project $1849 / 82$.

Dr. Emiliano Aguirre is Director of the National Museum of Natural Sciences, José Gutiérrez Abaseal 2, 28006 Madrid, Spain. He is Chairman of the ICS Pliocene-Pleistocene Boundary Working Group and President of INQUA Subcommission I-D.

Dr. Giancarlo Pasini is Secretary of INQUA Subcommission I-D and has been responsible for much of the work and coordination of results from the Vrica stratotype section. He works at the National Research Council Institute of Marine Geology in Bologna, Italy.
References

Alberdi, M.T. and Aguirre, E., 1975. Actas I Cologuio Internacional sobre Biostratigrafía Continental del Neógeno Superior y Cuaternario Inferior, 1974. Trabajos sobre Neógeno-Cuaternario (CSIC, Madrid), v. 4, p. 119; 139-141.

Colalongo, M.L., Pasini, G., Pelosio, G., Raffi, S., Rio, D., Ruggieri, G., Sartoni, S., Selli, R. and Sprovieri, R., 1982. The Neogene-Quaternary boundary definition: a review and proposal. Geografia Fisica e Dinamica Quaternaria, v. 5, no. 1, p. 59-68.

Colalongo, M.L., Pasini, G. and Sartoni, S., 1981. Remarks on the Neogene Quaternary boundary and the Vrica Section (Calabria, Italy). Bollettino Societa Paleontologica Italiana, v. 20, no. 2, p. 99-120.

Emiliani, C., Mayeda, T, and Selli, R., 1961. Paleotemperature analysis of the PlioPleistocene section at Le Castella, Calabria, southern Italy. Geological Society of America Bulletin, v, 72, no. 5, p. 679-688.

Hedberg, H.D. (ed.), 1976. International Stratigraphic Guide. A guide to stratigraphic classification, terminology and procedure. John Wiley and Sons, New York, 200p.

Mankinen, E.A. and Dalrymple, G.B., 1979. Revised geomagnetic polarity time seale for the interval 0-5 m.y. B.P. Journal of Geophysical Research, 84 (B2), p. 615-626.

Obradovich, J.D., Naeser, C.W., Izett, G.A., Pasini, G., Bigazzi, G., 1982. Age constraints of the proposed Plio-Pleistocene boundary stratotype at Vrica, Italy. Nature, v. 298 , no. 5869, p. 55-59.

Sastry, M.V.A., Kurien, T.K. Dutta, T.K. and Biswas, S. (eds.), 1981. Fìeld Conference Neogene-Quaternary Boundary. India 1979. Proceedings, Calcutta, Geological Survey of India, 24lp.

Selli, R., Accorsi, C.A., Bandini Mazzanti, M., Bertolani Marchetti, D., Bigazzi, G., Bonadonna, F.P., Borsetti, A.M., Cati, F., Colalongo, M.L., D'Onofrio, S., Landini, W., Menesini, E. Mezzetti, R., Pasini, G., Savelli, C and Tompieri, R., 1977. The Vrice section (Calabria, Italy), A potential Neogene-Quaternary Boundary Stratotype. Giornale di Geologia, 42(1), p. 181-204.

Tauxe, L., Opdyke, N.D., Pasini, G. and Elmi, C., 1983. Age of the PliocenePleistocene Boundary in the Vrica seetion, southern Italy. Nature, v. 304, no. 5922 , p. 125-129.

Tortorici, L., 1982. Analisi delle deformazioni fragili dei sedimenti postorogeni della Calabria. Bollettíno Societ Geologi Italia, v. 100, p. 291-308.

Van Couvering, J.A. et al., in press. The Neogene-Quaternary Boundary, Final report of IGCP Project 41 .

\section{Thin Section Preparation}

* Rocks * Soils * Ceramics * Refractories

* Concrete etc.

We can provide a machine system for all your thin section preparations, featuring automatic parallelism and thickness control.

*The most comprehensive, fully integrated machine systems for the production of FINISHED THIN SECTIONS . . .

For further details

PM2A

write to

AUTOMATED THIN SECTION SYSTEM

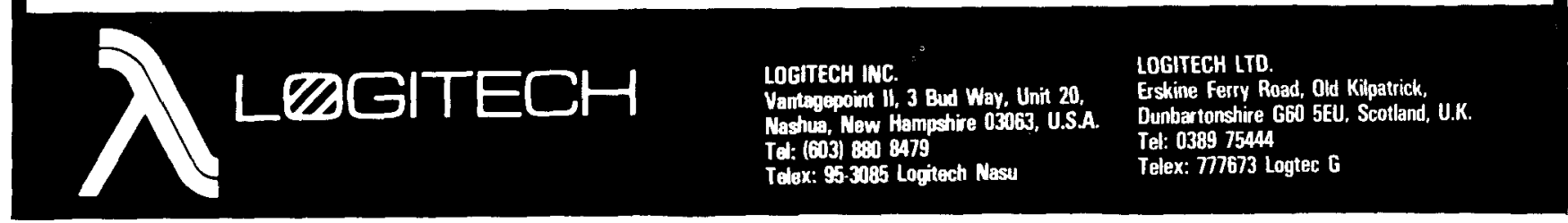

